\title{
Learner Views about a Distance Education Course
}

\author{
Gurhan Durak \\ Balikesir University, Turkey \\ Murat Ataizi \\ Anadolu University, Turkey
}

\begin{abstract}
The purpose of the study was to investigate the views of learners experienced in the Distance Learning Platform (DLP), which was prepared according to an online course design model. The participants of the study were 19 learners who took the programming languages course (via the DLP for 14 weeks). Before the application, the preparation of the DLP took nearly 500 hours. A pilot study was performed with the learners during the summer school. The design of the DLP was improved through the views of those learners. The data were obtained through face-to-face interviews with the learners. The following themes emerged from analysis of the data: factors in preferring the DLP, general characteristics of the DLP, the effectiveness of the DLP, and expansion of the DLP. These themes are further analyzed on the basis of "Diffusion of Innovations" and "Uses and Gratifications" theories. As a result of the interviews conducted with the learners, it was found that the learners had positive opinions about the DLP as it (1) offers flexibility, (2) contains elements enhancing their motivation, (3) enables the learners to communicate easily with the instructor, (4) provides the learners with instant feedback, and (5) enables them to access to the course materials easily.
\end{abstract}

Keywords: Distance education; Online learning; Instructional design model; Programming language; Learner views; Course evaluation

\section{Introduction}

Because it can successfully meet a wide range of educational needs of the modern societies through the revolutionary innovations it brings, online learning is demanded strongly by all types of organizations and settings, varying from businesses to educational institutions (Sun, Tsai, Finger, Chen \& Yeh, 2008).

Due to the high number of learners and financial restrictions in higher education, increases are observed in classroom sizes. When institutions fail at performing their duties of providing feedback and mid-term assessments, learners' bond with each other and with the school weakens. These shortcomings may result in students' failure to complete their higher education in due time (Stephen, O'Connell, \& Hall, 2008). To address this negative trend, some universities have opted to offer online courses with their advanced internet and computer technologies. According to Palloff and Pratt (1999), some universities have adopted this change in order to attract learners who did not attend the courses, and some others to meet the needs of the new generation of learners. 
"Horizon Report", which is published annually by "The New Media Consortium" examines and reports the recent technological advances in education technologies. In the reports for the past three years, the results have been supportive of online learning practices. According to the 2011 report; people expect to learn and work whenever and wherever they want, the trend in accessing information technologies has been evolving towards independence, and learning is becoming more autonomous (Johnson, Smith, Willis, Levine, \& Haywood, 2011).

Today's learners want to pursue their education based on the developing technology. They are not satisfied with the traditional methods, and they prefer to use the technological devices (computer, smart phone, tablet etc.) that they use in their lives, for their education as well. They are seeking ways to learn at their own learning speed, and in their own learning style (Van Der Werf \& Sebatier, 2009). Additional findings to support this are also cited in the Horizon Report 2012. According to this report; today's learners want to reach information in an effortlessly and timely manner, besides easily accessing information and receiving feedback. Such opportunities offered by informal learning are changing the expectations of learners (Johnson et al., 2012).

The new generation that is named as "network society", are very familiar with digital resources. These learners can be said to be almost surrounded by a digital spiral. They seek online social interaction and they want this interaction to be a part of their learning processes (Philip, 2007). According to Mabrito and Medley (2008), developing the dialogue among learners leads to the development and improvement of new ideas and opinions. At the same time, equipped with a computer network, a cooperation and communication network society enables its learners to meet their special learning needs.

A study on online learning indicates that the number of online learners reached from 1,6 million to 6,7 million between 2002 and 2011 in the United States. In this study, educators were asked to evaluate the inadequacy of online learning compared to traditional learning, and the findings showed that the number of participants who thought that it would be inadequate got lower and lower over the years (Allen \& Seaman, 2013). This rise in the number of online learners is observed not only in the United States but in many other countries, especially India and China. Some factors making online learning so popular around the world are the freedom that it offers about when to take a course, reducing the learning time, enabling learners to freely express their opinions and ask questions without any restrictions, and offering the option to choose in accessing course topics and relevant materials (Bouhnik \& Marcus, 2006).

The variety of the learning objects that is missing in traditional education can be applied on online courses. Thus, learners prefer online courses that include various course activities such as discussion forums (Tello, 2007). As learning becomes more individualized, learnercentered, settled, cooperative and available anywhere /anytime, e-learning technologies will also become more individualized, user-centered, network-based, long-term and available anywhere/anytime (Motiwalla, 2007).

While online practices have become so widespread and popular, they are known to have some drawbacks as well. These drawbacks can be summed up as: The technical problems that can arise in online learning environments (Alexander, Truell, \& Zhao, 2012; James, 2002; Song, Singleton, Hill, \& Koh, 2004), inability to meet the learning needs at learners' own speed (Hetzner \& Leen, 2013), not structuring it in a way to keep learners from taking it too easy (Alexander et al., 2012), lack of communication among learners and between learners and 
teachers (Alexander et al., 2012; Hetzner \& Leen, 2013; Song et al., 2004; Vonderwell, 2003), lack of quality materials appropriate for online learning or the unadapted inclusion of the materials used in traditional methods directly into online learning (Alexander et al., 2012; Hetzner \& Leen, 2013), difficulties in feedback (Alexander et al., 2012; Petrides, 2002; Jaggars \& Bailey, 2010; James, 2002; Vonderwell, 2003), some possible distractors and the resulting loss of learner motivation (Jaggars \& Bailey, 2010).

Another problem with online courses is the high rate of course incompletion or dropouts. It has been repeatedly found that the rate of online course completion is lower than face-toface courses (Diaz, 2002; Dutton, Dutton, \& Perry, 1999; Frankola, 2001; Murray, 2001; Lorenzetti, 2002; Meyer, 2012; Xu \& Jaggars, 2011, cited in Yuan and Powell, 2013). This is the case even with the most popular MOOCs (Simsek, 2015).

It can be said that the Programming Languages course is the most basic course in computer departments. As the foundation of some courses in the curriculum and also as a requisite skill for learners who aim to find a job in the private sector, this course is highly important. According to Bills and Biles (2005), Programming is also fundamental for information technologies. Despite its significance, according to Maltby and Whittle (2000), there are some challenges in teaching Programming Languages. These challenges are related to traditional education practices such as teaching Programming Languages in classrooms with high number of learners. The excessively high number of learners taking these courses has a negative impact on assessment (Westerlund, 2008) and giving feedback (Monks \& Schmidt, 2010), which results in lower motivation (McKeachie, 1990; Spahn, 1999) and success (Bandiera, 2009; Kokkelenberg, Dillon \& Christy, 2005; Kokkelenberg, Dillon, \& Christy, 2008).

Teaching courses that require constant application like Programming Languages in the classroom environment leads to receiving inadequate feedback by the learners (James, 2002; Petrides, 2002; Vonderwell, 2003) and their inability to practice immediately. In traditional methods, learner supervision is not at a sufficient level, and mostly learners can only be given face-to-face support. Furthermore, the fact that the instructors cannot spend enough time for the learners negatively affects learner interest and motivation for the course. Another problem is the physical inadequacies of the existing classrooms. The number of learners being much higher than the ideal is another negative factor on effective instruction.

\section{Relevant Research}

There have been many experimental studies and meta-analyses in the literature that compare online learning and traditional learning (e.g. Bernard, Abrami, Lou, Borokhovski, Wade, Wozney, Wallet, Fiset, \& Huang, 2004; Driscoll, Jicha, Hunt, Tichavsky, \& Thompson, 2012; Feintuch, 2010; Gunawardena \& Mclsaac, 2004; Joy \& Garcia, 2000; Quillen, 2010; Wilson \& Allen, 2011; Zhao, Lei, Yan, Lai, \& Tan, 2005). Some of these studies found no difference between the two methods (Ahmad \& Ives, 2001; Bernard et al., 2004; Borthick \& Jones, 2000; Driscoll et al., 2012; Friday, Friday-Stroud, Green, \& Hill, 2006; Gagne \& Shepherd, 2001; Gunawardena \& Mclsaac, 2004; Hiltz, 1994; Huh, Yoo, Jin, \& Lee, 2008; Piccoli, Rich, \& Dereshiwsky, 2011; Roseth, Saltarelli, \& Glass, 2011; Royse, 2000; Russel, 1999); while some others found that online learning is as much effective as, and even more than traditional learning (e.g. Aly, 2013; Cavus, Uzunboylu, \& Ibrahim, 2007; Daymont \& Blau, 2008; Farag, 2012; Feintuch, 2010; Jones \& Chen, 2008; Lapsley, Kulik, Moody \& Arbaugh, 2008; Kose, Koc, \& Yucesoy, 2013; Stivason, Saunders, \& Price 2008; Zhao et al., 2005). 
It can be said that online practices can yield the best results by incorporating the advantages of both synchronous and asynchronous environments, and by reducing their negative aspects. Although the analysis of the relevant literature reveals that the environments incorporating both synchronous and asynchronous communication tools are more effective (Hastie, Hung, Chen, \& Kinsuk, 2010; Simonson, Smaldino, Albright, \& Zvacek, 2012), distance education is given asynchronous mostly (Hrastinski, 2008; Palloff \& Pratt, 1999; Swan, 2002; Wang, 2008). Moreover, it was seen that in the literature instructional design models were not taken into consideration in most of the online courses. The Distance Learning Platform that is prepared within the scope of this study aims to address this gap in the literature. Following the recent changes in the education system, this study presents the online preparation and application of an undergraduate course and the learner views about online learning. As such, the purpose of this study is to analyze the learner views regarding an online course that was designed according to learning design models.

\section{Theoretical Framework}

This study is grounded upon both the Uses and Gratifications Theory (UGT) and the Diffusion of Innovations Theory. Both of these theories provide an appropriate basis for research about communication, media and new technologies. The data in this study were analyzed within the context of these theories.

\section{Diffusion of Innovations Theory}

This theory was suggested by Rogers (2003) and it consists of four main elements: innovation, communication channels, time, and a social system. Rogers defined "innovation" as an idea, an application or an object considered to be new by an individual or organization. An innovation doesn't have to be a concept or a design that is definitely unknown or familiar. If the individuals or organizations have not used it yet, it can be considered as an innovation (Berger, 2005).

There are five phases in the innovation-decision process: knowledge, persuasion, decision, implementation, and confirmation. Knowledge: The individual gets informed about the innovation and its use. Persuasion: The individual evaluates the positive and negative aspects of the innovation and shapes his/her attitudes accordingly. Decision: The individual decides to accept or reject the innovation. Implementation: If the individual decides to accept the innovation, he/she employs it to a varying degree depending on the situation. Confirmation: If the individual finds the innovation useful, he/she finalizes his/her decision whether to continue using it (Orr, 2003). In this research, DLP is regarded as an innovation for students, because they have not used it before this study. 


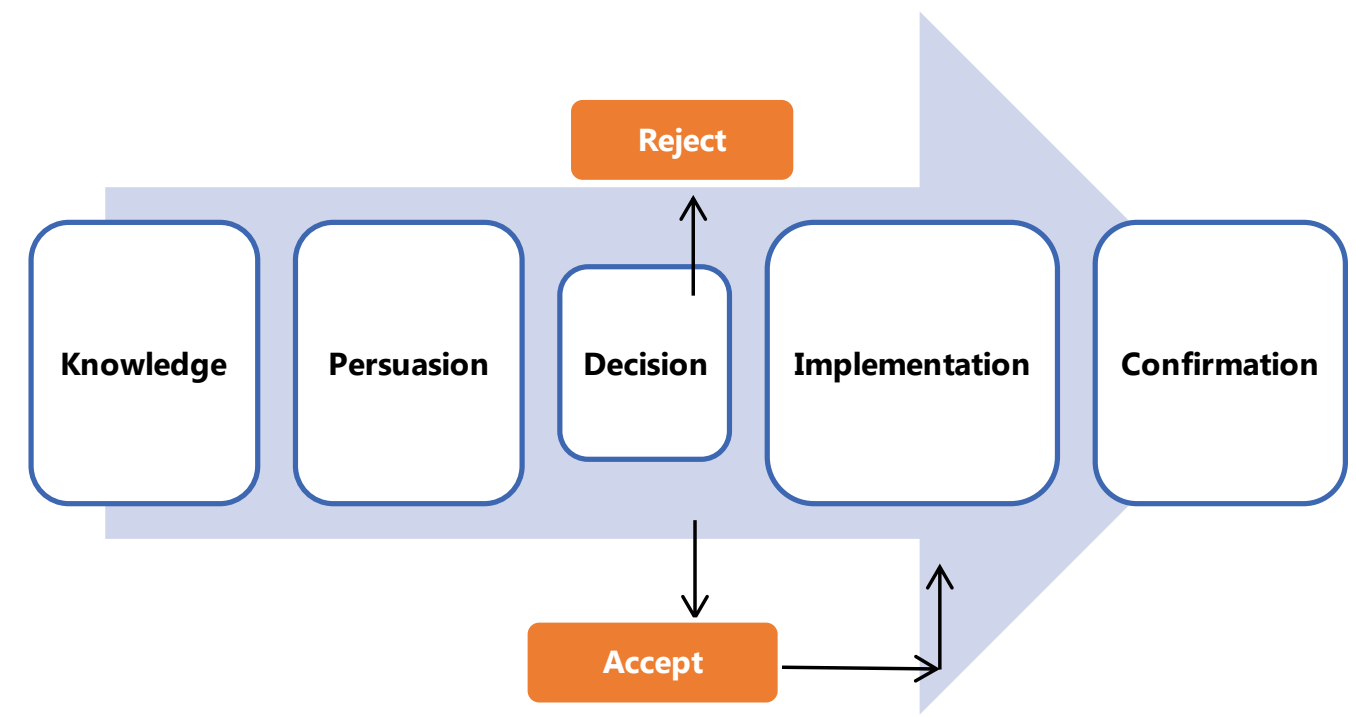

Figure 1. The Innovation-Decision Process (Rogers, 1995)

\section{Uses and Gratifications Theory}

This theory was first announced by Kats. According to Katz, research on communication focused on the question of "What media do to people?" but the real question had to be "What people do with media?" (McQuail \& Windahl, 2010, p.167).

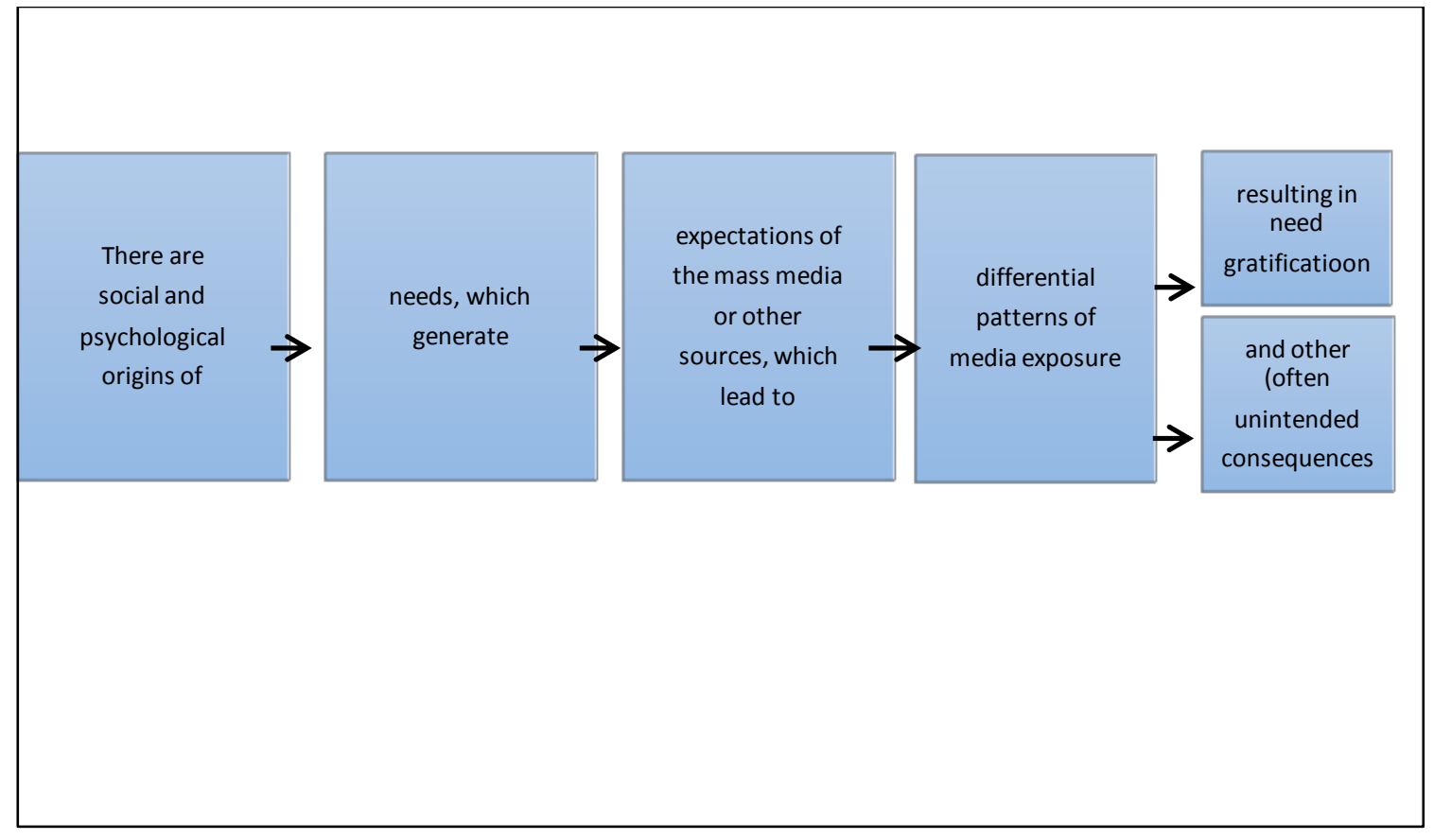

Figure 2. The Uses and Gratifications Approach (McQuail \& Windahl, 2010, p.168)

Katz and Blumler (1974) who grounded their research on UGT suggested that there are five types of requirements for people to use mass communication media: (1) cognitive needs (related to strengthening information, knowledge, and understanding), (2) affective needs 
(related to strengthening aesthetic, pleasurable, and emotional experience), (3) personal adaptation needs (related to strengthening credibility, confidence, stability, and status), (4) social adaptation needs (related to strengthening contact with family, friends, and the world, (5) escape needs (related to escape or tension-release from the daily stress.

\section{Method}

\section{Research Model}

The purpose of this study was to elicit learners' views on their experiences of using the Distance Learning Platform (DLP) that was developed as a part of the Programming Languages I course in the Computer and Instructional Technologies Education (CEIT) undergraduate program. For this purpose, the qualitative research design was used. Overall, this study focused on collecting in-depth data from the learners about their DLP experience, and on determining learners' preferences, expectations, and anxieties before and after taking an online course.

\section{Data Collection Tools}

The data were collected through a semi-structured interview form, which is a frequently-used interview type. Interview is a method that is used to collect participants' views, opinions, and knowledge about a certain topic through an interview form. It is usually one of the most important data collection methods in qualitative research. According to Chaleunvong (2009), data can be collected by taking notes during or immediately after the interview, or can be collected by using a voice recorder during the interview. The purpose of the interview is, learning what the participant has in mind and knowing what he or she thinks and feels about something. Since feelings, opinions, and intentions cannot be directly observed, in this type of situations the participants can be asked questions through interviews (Fraenkel \& Wallen, 2003). The interview technique is used as the shortest cut to learn about individuals' knowledge, opinion, attitude and behaviors and/or the possible reasons for having them (Karasar, 1999). The semi-structured interview form used in this study is a technique that open-ended questions are asked by using an interview form, whereby the data are usually collected as a voice-recording (Creswell, 2009).

In the preparation of questions, the theoretical information obtained by analyzing the relevant literature and the theories underlying the study were considered and accordingly an interview form was drafted. This draft of the interview form was analyzed by educational technology and assessment experts. Based on their feedback, its final version was prepared. This final version was analyzed by 3 research assistants and it was decided to be legible and applicable upon high percentage of agreement.

\section{Participants}

The participants of the study were 19 undergraduate students who took the Programming Languages I course during the 2012-2013 academic year in the CEIT Department of Balıkesir University in Western Turkey. In the preparation of the sample, some criteria had to be met in determining who would become the online students from among all the learners. Among 
these criteria were: having regular internet connection and a comfortable study environment and being willing to participate in the study. Therefore, the purposeful sampling method was preferred for this study.

\section{Data Analysis}

The NVivo software was used for data analysis. The one-on-one interviews conducted with the learners were collected as voice recordings. During these interviews, the participants were given detailed information about the purpose and methods of the study and each interview lasted approximately for 10 minutes. After the interviews, the voice recordings were transcribed into texts exactly as told by the learners without any additions or deletions. Then, in accordance with the pre-determined coding scheme, the questions and answers were presented in tables.

The transcribed interview recordings were analyzed one by one and the researchers made their own interview coding keys. To ensure the reliability of the coding keys, their consistency was analyzed by the researchers and a field expert. After reaching an agreement about the consistency, the data were thematized on the theoretical basis of the study. Additionally, so as to effectively reflect the learner views, they were often directly quoted.

The data analysis process in qualitative research is composed of description, analysis, and interpretation stages (Yildirim \& Simsek, 2008). In the description stage, what the interviewed individuals have said is sought to be determined. In the analysis stage, the relationships between the themes arising from the data and the relevant data are established. Finally, the process is completed by the interpretation of the obtained findings.

\section{Validity and Reliability}

Before the individual interviews were conducted, the participants were informed that their views would only be used for a scientific study and their real names would certainly be kept anonymous. The validity is aimed to be achieved by eliciting their honest views in this way. All the interviews were recorded with a voice recorder.

In order to ensure reliability, the findings were presented without comments. The researchers and an experienced scholar on qualitative research designs worked together on the findings. Furthermore, interview recordings, their transcripts, and the codings were saved so that they can be checked later by other researchers.

\section{Preparation of the DLP}

The DLP designed for this study was developed according to the ADDIE design model, and it included online course design elements. In the application of the ADDIE design model, its ease of the application, its flexibility, its offering systematic progress, and its allowing not only a linear process but also going back to the previous stages are some important advantages (Vejvodova, 2009). Based on the analysis, design, development, implementation, and evaluation stages of the ADDIE model, the DLP went through these processes: In the analysis stage; needs analysis, learner analysis, content analysis, technical analysis, structural analysis, 
online environment analysis were conducted. In the design stage; after defining the objectives, the designs of the communication elements, support services, course schedule, course contents, technological infrastructure, evaluation system and online environments were carried out. In the development stage; the preparation of the DLP, dividing the course into modules and developing the modules, preparing the contents and developing the evaluation system steps were conducted. In the implementation stage; first introduction and use of the system were ensured, by supporting the learning environment various activities were prepared to enhance the communication environments, and eventually after the course began to be taught, this process was maintained. In the final stage, the evaluation, besides the midterm assessments conducted by means of weekly group assignments, through individual interviews with the learners at the end of the semester, the evaluation stage was aimed to be completed.

The preparation of this course conducted with the DLP took about 500 hours. After its preparation, the piloting was carried out with the learners that were taking the Programming Languages course in the 2012-2013 summer school period. Based on the views that were elicited from the learners, the DLP was revised and the necessary modifications were made.

\section{Application Process}

The application of this course took 14 weeks. In the first week, learners were introduced the DLP and its use was ensured. After opening their member accounts, learners were given the necessary equipment (camera, microphone and headphones). After the necessary browser settings were conducted, first an orientation meeting was held for a trial run of the DLP with the learners. After the learners were told the rules about the course, they were demonstrated the use of the system devices. The DLP has an always-open asynchronous platform with course resources, notifications, assignments and course videos, and a synchronous platform where courses are taught live. The live courses were conducted at the predetermined times and durations of all the courses were recorded. The learners had the opportunity to watch these courses again and again whenever they wanted. The courses were taught in this way except for the midterm and final exam weeks, and after the finals learners' views regarding the DLP were obtained.

\section{Findings}

The data obtained through the face-to-face interviews with the learners were coded and these themes emerged: the factors in preferring the DLP, the general characteristics of the DLP, the effectiveness of the DLP, and expansion of the DLP. These themes are analyzed on the basis of "Diffusion of Innovations" and "Uses and Gratifications" theories.

\section{Reasons Given for Preferring the DLP}

The participants were asked how they had decided to take the "Programming Languages I" course through distance education, and the subthemes which are presented in Table 1 were obtained. 
Table 1. Reasons Given for Preferring the DLP

\begin{tabular}{lc}
\hline Themes & Frequency $(f)$ \\
\hline Getting away from the crowdedness of classroom environment \& comfort of & 13 \\
home & 9 \\
Curiosity about a new method & 4 \\
By obligation due to conflicting course hours & 7 \\
Thinking that the method is suitable for him/herself & $\mathbf{7}$ \\
\hline
\end{tabular}

Among the reasons provided by the participants for their preference of taking the Programming Languages I course via distance education are: their wish to get away from the disturbing effects of the traditional classroom environment and thinking that the course can be learned better in the comfort of their homes. Regarding this, a student named Zeki made this comment: "At the beginning of the semester, when I heard that our teacher was going to teach the course through distance education, I decided to take it because I thought I would be better motivated in home comfort without the classroom noise."

Other reasons leading the participants to take the course through distance education method are: thinking that this was a new method and thus feeling curious about it, and also that learning in this way would better suit their purposes. A student named Meltem expressed her view as: "When our teacher talked about this method it drew my attention. I got curious about it and told myself that it would help to try new things, besides I thought that I could drop it later if I didn't like it, so I decided to take this course via distance."

Some students taking the course cited their reason for choosing the distance method as the time conflict of the course with other courses. Ozgur said: "Since I am retaking this course, it was going to pose a problem for my school hours. The appeal of the distance course hours influenced on my choice."

It can be said that, the learners who preferred the DLP did this due to the comfort provided by this method that offers an alternative for time and location, its novelty, and offering course hours that are suitable for them.

\section{General Characteristics of the DLP}

The questions that were asked to the participants about the positive and negative aspects of the synchronous and asynchronous elements that constitute the DLP yielded the findings presented in Table 2. 
Table 2. General Characteristics of the DLP

\begin{tabular}{lc}
\hline Themes & Frequency (f) \\
\hline $\begin{array}{l}\text { Criticisms directed against the asynchronous platform } \\
\text { Layout of the forum files } \\
\text { Inadequacy of the notifications and chat sections } \\
\text { Forum page not staying up-to-date }\end{array}$ & 3 \\
& 2 \\
& 4 \\
\hline Positive qualities of the synchronous platform & \\
Its being a whole with multiple media & 9 \\
Course records being savable and re-watchable & 16 \\
Usability of the plug-ins like chat and Q\&A & 8 \\
& \\
\hline Negative qualities of the synchronous platform & 2 \\
Lack of Turkish language support & 11 \\
Technical problems & 4 \\
Browser-related & 2 \\
Connection-speed related & 5 \\
Equipment related (headphones, microphone) & 3 \\
Abusability of the private chat section & \\
\hline
\end{tabular}

The shortcomings of the asynchronous platform, which is a part of the DLP, were tried to be identified and the participants put forward some criticisms about the structure of the forum on the asynchronous platform. The participants found the layout of the files on the forum too complicated and also saw the forum page not being kept up-to-date as a shortcoming. Ziya expressed his criticisms as: "the forum section seemed to be inadequate, a more advanced forum system can be used. The category system in the forum is not very appropriate and the headings seem to be too complex".

Furthermore, the view that the notifications section and chat plug-in were not interactive enough also surfaced. A participant, named Tahsin explained: "the chat section can be made more interactive and if the messages sent through the system can also be sent as an e-mail to all the members, there will be no problem of not noticing the messages".

The synchronous (live course environment) platform, which is another component of the DLP, was evaluated by the participants and its qualities were classified under two headings as positive and negative. Among the positive elements of the platform, its quality of having multiple media together, the usability of its plug-ins such as chat and Q\&A emerged. A student named Zeki commented: "That Adobe Connect integrates sound, picture, screensharing, file-sharing and chat elements all together are very beneficial". The most-frequently mentioned quality was the recordability of the courses and thus it's offering the opportunity to the learner to watch the courses again. About this quality of the software, Meltem said: "Instead of asking our teacher to clarify the points I missed or couldn't understand, I watch the course videos. This way I do not interrupt the flow of the course". 
From the learners' views about the DLP, it can be said that its integration of multimedia is an important quality, especially the qualities of virtual classroom application is successful, and the recordability of the courses is found to be very useful for repetition but the layout section of the forum and the chat need improvement.

\section{Effectiveness of the DLP}

The participants were asked to compare the distance education that they have taken with the traditional education. This way, their evaluations about course attendance, motivation and to what extent they comprehended the course subjects were tried to be determined. From this set of data, the findings shown in Table 3 were elicited.

Table 3. Effectiveness of the DLP

\begin{tabular}{ll}
\hline Themes & Frequency $(\boldsymbol{f})$ \\
\hline Its superior aspects over the traditional methods & 14 \\
The comfort of the course environment-physical advantages & 10 \\
Scarcity of the factors to cause demotivation & 5 \\
The feeling of closeness to the teacher & 16 \\
Re-watchability of the courses & \\
Its weaknesses compared to the traditional methods & 4 \\
Negativities caused by technical problems & 5 \\
Demotivation caused by complacency & 3 \\
Shortcomings in communication & \\
Course comprehension levels & 16 \\
& 5 \\
Positive impact on course attendance and motivation & 3 \\
Suitability of course hours & 6 \\
The idea that they are monitored in the system & 2 \\
Timely feedback to their postings & 9 \\
The actions to keep the platform alive & 11 \\
Cooperative learning environment & 16 \\
Benefits gained from the group assignments & \\
Direct access to course resources &
\end{tabular}

The participants were asked to compare the DLP with the traditional methods, and DLP's strengths and weaknesses are grouped under two headings. Almost all the participants mentioned the physical advantages of learning through distance education. Not having the distracting factors of classroom environment in the comfort of home atmosphere, and thus being less demotivated is regarded as a superiority. A student named Zeynep reported "we can ask questions and get answered promptly. There are no factors like noise. This increases motivation". Some of the participants reported that they cannot easily ask questions to the teacher in the classroom environment because they shy away but in this online environment they can easily ask everything they want. As the common opinion of all the participants, one of the most prominent qualities of this method is its opportunity enabling the learners to watch the course videos whenever they want. A student named Nefise said: "In my opinion, the fact that we are sharing the recorded course videos, resources, assignments and other files 
through the system, and these are viewed and downloaded by all other students is very helpful".

Based on the responses to the questions that were seeking to determine the weaknesses compared to traditional methods, the participants talked about a few negativities caused by some technical problems. In addition, the motivation loss caused by complacency is also viewed as negative. A student, Sercan said "Its not being face-to-face and offering too much comfort sometimes lowers the interest in the course". Finally, several participants claimed that there were some inadequacies in the DLP regarding communication. A student named Meltem made this comment on this issue: "Due to the lack of face-to-face communication, effective communication cannot be properly ensured."

Finally, the participants were asked whether they thought that they comprehended the course, and whether this method was helpful in terms of course attendance and motivation, and a category was created under the heading "course comprehension levels." The participants reported that the course hours were very convenient, and since they thought that the system monitored them, their motivation increased, they were also less absent from the course.

Omer made this comment regarding the course hours: "Since I both study and work, I was unable to attend the courses in formal education, the biggest challenge for me was attendance. I think that this method is perfect for me. At the end of the business day, I come home and I log on to my course after I rest. I feel more motivated and eager to listen to the course". Thinking that she is monitored through the DLP, Meltem expressed her view as: "Our teacher can see all our data on the DLP, like how much of the subject we have completed, where we have visited, and so on. Knowing this encourages us to spend some more effort. This motivated me, to be honest". Regarding keeping the system alive, Fatmanur expressed her view as: "First of all, I feel like our teacher is always on the computer. For example, I study more at night, when I have a question, I write that and I get the answer quickly. Normally, I would have to wait for the next class, but with this system, I believe that the distance is removed. Besides, thanks to the notices, messages and files that our teacher posts on the system, we are constantly thinking of this course now". Regarding cooperative learning, a learner named Nefise commented as: "Our teacher asked us to form small groups. Every week, assignments and discussions topics were posted on the system. This way, we discussed the assignments not as individuals but as a group, and we divided the tasks. I think it was useful in this way".

Based on the elicited answers; it can be said that the learners view the DLP as an efficient system, they become more motivated with this method, the comfort of the home and the flexibility of the course hours make them more eager to learn, they can usually get timely answers to their questions, knowing that they are monitored by the system lead them to take the course seriously, but also there may be some drawbacks due to too much complacency, and that some learners still seek face-to-face interaction.

\section{Expansion of the DLP}

The participants were asked about their views regarding the expansion of practices like DLP, considering the future of distance education. Their views were sought about which courses this type of methods would be more appropriate, which social groups may need them, and 
their preferences for using this kind of practices. From these data, the findings presented in Table 4 were elicited.

Table 4. Expansion of the DLP

\begin{tabular}{lc}
\hline Themes & Frequency(f) \\
\hline Application for other courses & 7 \\
Common courses of the universities (Computer, History, Turkish, & \\
English) & 5 \\
In verbal courses & 6 \\
In other courses in the department & \\
\hline General views on its expansion & 7 \\
This type of practices will be the basis of future education system & 8 \\
It can meet workers' education needs & 6 \\
It can be preferred for temporal, spatial or financial reasons & 4 \\
It suits higher education better & \\
\hline
\end{tabular}

The participants were asked about what other courses (departmental or non-departmental) the distance education method through which they had taken the Programming Languages I course could be applied in. The answers generally indicate that it would be better to apply it in verbal courses. The participants also think that this method should be tried in some common courses at the universities (Computer, Turkish, English, History etc.). Regarding this, a student named Abdulkadir said "In my opinion, it would be better for it to be in the non-area courses in the department. For example, instead of going to school to take courses such as English, Turkish, history, I would rather take these courses via distance education".

As for the issue about which the participants' views were also sought, the expansion of DLP practices, the common view is that this type of practices will be often used in the education system in the future. Ismail expressed his opinion on this as: "Since technology and the internet have improved, it will be convenient for many students. I think this will be very helpful for those who cannot go to school for whatever reason." The emerging view here is that distance education is a method that can be a solution for the education needs of employees, and, by allowing people to receive education whenever and wherever, it ensures life-long learning. Regarding this point, a student named Ziya commented: "Distance education will be very helpful for some people. For example, those who want to improve themselves professionally after starting to work can easily do this through distance education by studying at another university". Similarly, students who think that it should be expanded also stated that since this method requires some technological and cognitive background, it should be applied more in higher education. Ufuk said: "I believe that most universities will use this system in the future. I think it is very suitable for a master's degree; after all, there are some requirements to be able to benefit from this system".

Finally, the participants were asked whether they would use in such a system in their courses in the future and most of them replied that they would think about using it. Concerning this issue, a student named Nefise commented: "Of course, it's possible. Monitoring how much the students work, to what degree they do their homework, their postings, etc. will ensure more effective course instruction". 
Based on the answers elicited from the learners; it can be said that, expansion of distance education practices like the DLP offers an opportunity for those who cannot go to school for some reason or for workers, besides offering a useable method for postgraduate education. Overall, learners supported the expansion of such practices.

\section{Results, Discussion, and Recommendations}

Seeking the views of learners who have experienced the DLP, in this study the learner views are classified under the following categories: the reasons for preferring the online learning conducted via the DLP, positive and negative qualities of the DLP, effectiveness of the DLP, and views about the expansion of online environments like the DLP.

Almost all of the learners reported that the online course they have taken through the DLP offered great convenience in terms of time and location, and these factors played a crucial role in their preference of this course. These findings that emerged in this study are also supported by the flexibility factor that was underscored in the studies on distance education or online learning (Ally, 2004; Anderson \& Simpson, 2012; Bouhnik \& Marcus, 2006; Gulbahar, 2009; Hiltz \& Tusoff, 2005; Hratinski, 2008; Johnson et al., 2011; Oblinger \& Oblinger, 2005; Motiwalla, 2007; Sun et al., 2008; White, 2003).

Another factor leading the learners to prefer this course that was carried out through the DLP can be given as their thinking that the course instruction and the structure of online learning is more suitable for them. As such, learners reported that the course hours were more convenient for them and that they preferred online learning because they thought it would not pose problems such as classroom noise and other demotivating problems of the traditional method. It can be said that, these learners know their responsibilities, are aware that learning occurs as a result of their own activities, and embrace the learner-centered education. As stated repeatedly in the Independent Study Theory, the individualization of learning, realization of learning through the learner's own activities, and each learner's assuming his/her own responsibility (Pyari, 2011, cited in Wedemeyer, 1981) support the learner responses in the present study.

When asked about the DLP's positive and negative aspects, learners stated that, the DLP's integration of multiple media together was able to meet all their needs. The learners found it very helpful to be able to easily communicate among themselves and with the course instructor, and also to access course resources anytime they wanted. This finding that asynchronous environments within online learning enables learners to easily access to documents at will, as well as the means to send messages to teachers and to other learners is similar to what has been found in other studies (i.e. Hratinski, 2008) in the literature.

In addition to the positive features indicated above, the learners pointed out some problems regarding the synchronous environment (Adobe Connect). Among these, browser-related problems, equipment-related (such as microphone and headphones) problems and, though a few, disconnections experienced in the synchronous courses are mentioned. The browserrelated problems can be said to result from the lack of updating. It can be concluded that, although carefully explained during the orientation course, the camera, microphone, and headphone settings were not properly adjusted by the learners. Finally, among the primary reasons for the disconnections experienced in the synchronous courses, the temporary failures in some learners' connections, the slowing-down of the connection speed due to 
shared internet use (dormitory environment) can be counted. These problems can be solved by improving the connection speeds. Furthermore, the teacher holds the position of a presenter (server) and thus, his/her connection speed (Upload) needs to be higher depending on the number of learners.

The learners were asked to compare their traditional learning experiences and their online learning experience of the DLP. The learners talked about the convenience and advantages of the DLP, and expressed that it has fewer distracting factors than that of the traditional classroom environment and that they feel closer to the course instructor. The reasons for these given views can be said to result from the fact that they are very familiar with computers and that computer use is an inseparable part of their lives, and they read and write on paper less often than the other learners. This is supported by the findings in the relevant literature, demonstrating that, not satisfied with the traditional methods, todays' learners want to pursue their education around the advancing technology and thus they prefer to use the technological devices that they use in their daily lives in their education as well (Van Der Wer \& Sebatier, 2009), and that the new generation is very familiar with digital resources, and they have less experience of reading (Prensky, 2001).

One of the drawbacks of the traditional learning is the difficulty that learners have in asking questions to teachers easily. Judging by the learner views and system logs, it is known that the learners taking the DLP do not have any difficulties in reaching the teacher; on the contrary, they are quite comfortable about this. This result is also supported by the finding that the difficulty that learners have in asking questions to teachers easily in the traditional methods can be solved through online learning (Cavus, 2007).

That the DLP courses are recorded and the learners can watch these anytime they want, the opportunity to access the course resources directly, learners' awareness of being monitored through the DLP and thus taking the course more seriously, the timely feedback they receive for their postings and the benefits that they gain from the group assignments are reported by the learners as the positive qualities of the DLP. Supporting these views, Watters and Robertson (2009) found that learners are very happy to be able to easily access the course resources and conveniently check them wherever they want. It can also be said that, as a result of the timely feedback provided by the teacher, learners' motivation for the course is ensured. This is supported by the argument that when learners do not receive feedback in a short time, they may think that they are struggling in vain, and thus may lose their learning motivation (Branon \& Essex, 2001, cited in Tolu, 2010). Moreover, learners talked about the benefits of group assignments, reporting that these affected them positively. This view is supported by the relevant literature demonstrating that cooperation yields positive outcomes (Cavus and Ibrahim, 2009; Kearsley, 2000; Johnson et al., 2011; Johnson et al., 2012; Mabrito \& Medley, 2008; Tello, 2007).

Learners expressed some negative comments like motivation loss due to too much complacency and shortcomings in communication about the online course conducted via the DLP. However, some learners can be thought to have dealt with off-task things during the course, no matter how closely they were monitored. Given the comfort of their home, these learners' attention may have shifted elsewhere. Regarding the criticisms on communication, some learners can be said to hold on to their traditional learning habits. This can be explained by some learners' search or desire for face-to-face interaction and the physical closeness of a classroom environment. 
The learners, having had the online course experience through the DLP, were asked what they thought about the expansion of online practices. From the answers given for this question, it can be concluded that the DLP developed for the Programming Languages course, can be adapted for the courses in other universities. This result relates with some basic tenets of one of the foundational theories of distance education, Industry Theory, such as mass production and standardization (Peters, 1988, cited in Gulbahar, 2009). The learners agreed that this type of practices should be expanded. Such practices can be easily implemented especially with responsible learners. It can be used in some postgraduate level courses in higher education, as well. Thanks to one of the characteristics of online learning, that is, time and location flexibility, workers' education needs can be met. Furthermore, the learners also agreed that the future of the education system is moving towards online learning. This view is supported by both the popularization of Massive Open Online Courses (MOOCs), and the projects announced by TUBITAK (The Scientific and Technological Research Council of Turkey).

In light of these results, to create a quality online course, the following points need to be taken into account: Conforming with the online course design principles, ensuring the communication of learners with one another, with the content, with the interface and with the teacher, offering the course resources for direct access, providing adequate guidance service and timely feedback, ensuring the ideal learner number and the supervision of the learners, providing the learners with social support and sufficient motivation, instead of providing only synchronous or only asynchronous practices, using these environments together, teachers' allowing enough time for course preparation, preparing cooperative tasks by employing activities like group assignments, supplying the equipment components that are necessary for the course, making sure that the course hours are convenient for the learners, and sustaining this status.

\section{References}

Alexander, M.W., Truell, A.D. \& Zhao, J.J. (2012). Expected advantages and disadvantages of onlıne learning: Perceptions from college students who have not taken online courses. Issues in Information Systems, 13(2), 193-200.

Allen, I.E. \& Seaman, J. (2013). Changing course: Ten years of tracking online education in the United States. Wellesley MA: Babson College/Quahog Research Group.

Ally, M. (2004). Foundations of educational theory for online learning. In T. Anderson (Ed.), The theory and practice of online learning (pp. 3-31). Athabasca, Alberta, Canada: Athabasca University.

Aly, i. (2013). Performance in an online introductory managerial accounting course in a classroom setting. Canadian Journal of Higher Education, 43(2), 85-99.

Anderson, B. \& Simpson, M. (2012). History and heritage in distance education. Journal of Open, Flexible, and Distance Learning, 16(2), 1-10.

Bandiera, O., Larcinese, V., \& Rasul, I. (2010). Heterogeneous class size effects: New evidence from a panel of university students. The Economic Journal, 120(549), 1365-1398

Bernard, R.M., Abrami, P.C., Lou, Y. Borokhovski, E., Wade, A. Wozney, L., Wallet, P.A., Fiset, M., \& Huang, B. (2004). How does distance education compare to classroom instruction? A meta-analysis of the empirical literature. Review of Educational Research, 74(3), 379-439. 
Berger, J. I. (2005). Perceived consequences of adopting the Internet into adult literacy and basic education classrooms. Adult Basic Education, 15(2), 103-121.

Bills, D.P \& Biles, J.A. (2005). The role of programming in IT. SIGITE'05 Conference (pp. 43-49). Newark, New Jersey.

Borthick, A. F. \& Jones, D. R. (2000). The motivation for collaborative discovery learning on line and its application in an information systems assurance course. Issues in Accounting Education, 15(2), 181-210.

Bouhnik, D. \& Marcus, T. (2006). Interaction in distance-learning courses. Journal of the American Society for Information Science and Technology, 57(3), 299-305.

Cavus, N. (2007). Assessing the success rate of students using a learning management system together with a collaborative tool in web -based teaching of programming languages. Journal of Educational Computing Research, 36(3), 301-321.

Cavus, N. \& Ibrahim, D. (2009). mLearning: An experiment in using SMS to support learning new English language words. British Journal of Educational Technology, 40(1), 78-91.

Cavus, N., Uzunboylu, H., \& Ibrahim, D. (2007). Assessing the success of students using a learning management system and together with a collaborative tool in web-based teaching of programming languages. Journal of Educational Computing Research, 36(3), 301-321.

Chaleunvong, K. (2009). Data collection techniques. Geneva Foundation for Medical Education and Research. Retrieved on 5 February 2015 from http://www.gfmer.ch/Activites_ internationales_Fr/Laos/Data_collection_tecniques_Chaleunvong_Laos_2009.htm

Creswell, J.W. (2009). Research design: Qualitative, quantitative, and mixed methods approaches ( ${ }^{\text {rd }}$ ed.). Los Angeles, CA: Sage.

Daymount, T. \& Blau, G. (2008). Student performance in online and traditional sections of an undergraduate management course. Institute of Behavioral and Applied Management, 9(3), 275-294.

Diaz, D. P. (2002). Online drop rates revisited. The technology source (Online). Retrieved on 8 September 2015 from http://technologysource.org/article/online_drop_rates_ revisited/

Driscoll, A., Jicha, K., Hunt, A.N., Tichavsky, L., \& Thompson, G. (2012). Can online courses deliver in-class results? A comparison of student performance and satisfaction in an online versus a face-to-face introductory sociology course. Teaching Sociology, 40(4), 312-331.

Dutton, J., Dutton, M., \& Perry, J. (1999). Do online students perform as well as lecture students? Journal of Engineering Education, 90(1), 131-139

Farag, W. (2012). Comparing achievement of intended learning outcomes in online programming classes with bl. Calgary, Alberta, Canada: Mount Royal University.

Feintuch, H. (2010). Keeping their distance: New study indicates students perform better online. Diverse: Issues in Higher Education, 27(3), 20.

Fraenkel JR. Wallen NE. (2003). How to design and evaluate research in education. Boston: McGraw-Hill.

Frankola, K. (2001). Why online learners dropout. Workforce, 10, 53-63. 
Friday, E., Friday-Stroud, S. S., Green, A. L., \& Hill. A. Y. (2006). A multi-semester comparison of student performance between multiple traditional and on line sections of two management courses. Journal of Behavioral and Applied Management, 8(1), 66-81.

Gagne, M. \& Shepherd, M (2001). Distance learning in accounting: A comparison between a distance and traditional graduate accounting class. T.H.E. Journal, 28(9), 58-65.

Gunawardena, C. N. \& Mclsaac, M. S. (2004). Distance education. In D. H. Jonassen (Ed.), Handbook of research on educational communications and technology (pp.355-396). Mahwah: Erlbaum.

Gulbahar, Y. (2009). e-ogrenme. Ankara: Pegem.

Hastie, M., Hung, I-C., Chen, N-S., \& Kinshuk (2010). A blended synchronous learning model for educational international collaboration. Innovations in Education and Teaching International, 47(1), 9-24.

Hetzner S., Leen, E. (2013). Personalisation and tutoring in e-Learning - The key for success in learning in later life. European Journal of Open, Distance and E-Learning, 17(1). Retrieved on 5 February 2015 from http://www.eurodl.org/index.php?p=special\&sp $=$ articles\&inum $=5$ \&article $=626$

Hiltz, S. R. (1994). The virtual classroom: Learning without limits via computer networks. Norwood NJ: Ablex.

Hiltz, S. R., \& Turoff, M. (2005). Education goes digital: The evolution of online learning and the revolution in higher education. Communications of the ACM, 48(10), 59-64.

Hrastinski, S. (2008). Asynchronous and synchronous e-learning. EDUCAUSE Quarterly, 31(4), 51-55.

Huh, S., Yoo, S., Jin, J., \& Lee, K.. (2008). Comparisons of performances between online learners and offline learners across different types of tests. Academy of Information and Management Sciences Journal, 11(1), 45-63.

Jaggars, S. S. \& Bailey, T. (2010) Effectiveness of fully online courses for college students: Response to a Department of Education meta-analysis. Teachers College, Columbia University, Community College Research Center. Retrieved on 5 February 2015 from http://www.icde.org/filestore/News/2004-2010/2010/ResponcetoaDept. ofEducationUSAMeta-Analysis.pdf.

James, G. (2002). Advantages and disadvantages of online learning. Retrieved on 5 February 2015 from http://www.leerbeleving.nl/wbts/nieuw_basics/addis.pdf.

Johnson, L., Adams, S., and Cummins, M.(2012). The NMC Horizon report: 2012 Higher Education Edition. Austin, Texas: TheNew MediaConsortium. Retrieved on 5 February 2015 from http://www.nmc.org/pdf/2012-horizon-report-HE.pdf (12.01.2013)

Johnson, L., Smith, R., Willis, H., Levine, A., and Haywood, K. (2011). The 2011 Horizon report. Austin, Texas: The New Media Consortium. Retrieved on 5 February 2015 from http://net.educause.edu/ir/library/pdf/hr2011.pdf.

Jones, K. T., \& Chen, C. C. (2008). Blended learning in a graduate accounting course: Student satisfaction and course design issues. The Accounting Educator's Journal, 18, 15-28.

Joy, E. \& Garcia, F. (2000). Research paper questions 'No Significant Difference' claims. Journal of Asynchronous Learning Networks, 6(1), 21-39. 
Karasar, N. (1999). Bilimsel arastirma yontemi- Kavramlar, ilkeler, teknikler. Ankara: Nobel .

Katz, E., \& Blumler, J. G. (1974). The uses of mass communications: Current perspectives on gratifications research. Beverly Hills: Sage.

Kearsley, G. (2000). Online education: Learning and teaching in cyberspace. Belmont, CA: Wadsworth.

Kokkelenberg, E. C., Dillon, M. \& Christy, S. M. (2005). The effects of class size on student achievement in higher education. Cornell Higher Education Research Institute (CHERI). Retrieved on 5 February 2015 from http://digitalcommons.ilr.cornell.edu/cheri/24/.

Kokkelenberg, E. C., Dillon, M. \& Christy, S. M. (2008). The effects of class size on student grades at a public university. Economics of Education Review, 27(2), 221-33.

Kose, U., Koc, D., \& Yucesoy, S. A. (2013). Design and development of a sample "computer programming" course tool via story -based e-learning approach. Educational Sciences: Theory \& Practice, 13(2), 1235-1250.

Lapsley, R., Kulik,B., Moody, R., Arbaugh, J. (2008). Is identical really identical? An investigation of equivalency theory and on line learning. The Journal of Educators Online, 5(1), 1-19.

Lorenzetti, J. P. (2002). Before they drift away: Two experts pool retention insights. Distance Education Report, 6(8), 1-2.

Mabrito, M. \& Medley, R. (2008). Why Professor Johnny can't read: Understanding the net generation's texts. Innovate: Journal of Online Education, 4(6). Retrieved on 5 February 2015 from http://www.editlib.org/j/IJOE/v/4/n/6/

Maltby, J. R., \& Whittle, J. (2000). Learning programming online: Student perceptions and performance. ASCILITE, 2000 Conference. Retrieved on 5 February 2015 from http://www.ascilite.org.au/conferences/coffs00/papers/john_maltby.pdf

McKeachie, W. J. (1990) Research on college teaching: The historical background. Journal of Educational Psychology, 82(2), 189-200.

Mcquail, D. \& Windahl, S. (2010). Iletisim modelleri (6 ${ }^{\text {th }}$ ed.). (Çev. K.Yumlu). Ankara: Imge.

Monks, J., Schmidt, R. (2010). The Impact of Class Size and Number of Students on Outcomes in Higher Education. Cornell Higher Education Research Institute (CHERI).

Motiwalla, L.F. (2007). Mobile learning: A framework and evaluation. Computers \& Education, 49, 581-596.

Murray, B. (2001). What makes students stay. eLearn Magazine. Retrieved on 5 February 2015 from http://elearnmag.org/subpage/sub_page.cfm?article_pk=1301\&page_ number_nb=1\&title=FEATURE\%20STORY.

Oblinger, D. G., \& Oblinger, J. L. (2005). Educating the net generation. EDUCAUSE. Retrieved on 5 February 2015 from http://net.educause.edu/ir/library/pdf/pub7101.pdf.

Orr, G. (2003). Diffusion of innovation by Everett Rogers (1995). Retrieved on 5 February 2015 from http://www.stanford.edu/class/symbsys205/Diffusion\%20of\%20Innovations.htm

Palloff, R. M. \& Pratt, K. (1999). Building learning communities in cyberspace: Effective strategies for the online classroom. San Francisco, CA: Jossey-Bass. 
Petrides, L.A. (2002). Web-based technologies for distributed (or distance) learning: Creating learning-centered educational experiences in the higher education classroom. International Journal of Instructional Media, 29(1), 69-77.

Philip, D. (2007). The knowledge building paradigm: A model of learning for Net Generation students. Innovate: Journal of Online Education, 3(5). Retrieved on 5 February 2015 from http://www.editlib.org/j/IJOE/v/3/n/5/

Piccoli, G., Rami A., \& Blake I. (2001). Web-based virtual learning environments: A research framework and a preliminary assessment of effectiveness in basic IT skills training. MIS Quarterly, 25(4), 401-26.

Pyari, D. (2011). Theory and distance education: At a glance. IPCSIT (12). Singapore: IACSIT Press.

Quillen, I. (2010). E-learning delivery debated. Education Week, 29(30), 5.

Rich, A.J. \& Dereshiwsky, M.I. (2011). Assessing the Comparative Effectiveness of Teaching Undergraduate Intermediate Accounting in the Online Classroom Format. Journal of College Teaching \& Learning, 8(9), 19-28.

Rogers, M.E. (1995). Diffusion of Innovations (4.ed.). New York: The Free Press.

Rogers, M. E. (2003). Diffusion of innovation (5.ed.). New York: The Free Press.

Roseth, C. J.,Saltarelli, A. J., \& Glass, C. R. (2011). Effects of face-to-face and computermediated constructive controversy on social interdependence, motivation, and achievement. Journal of Educational Psychology, 103(4), 804-820.

Royse D. (2000). Teaching Research over the Internet: An evaluation. Journal of Teaching in Social Work, 20(1), 145-158.

Russell, T. L. (1999). The no significant difference phenomenon. Montgomery, AL: International Distance Education Certification Center.

Simonson, M., Smaldino, S., Albright, M., \& Zvacek, S. (2012). Teaching and learning at a distance: Foundations of distance education ( $5^{\text {th }}$ ed.). Boston: Pearson.

Simsek, A. (2015). Do massive open online courses offer a viable solution for essential problems in higher education? In J. Lam, K. K. Ng, S. K. S. Cheung, T. L. Wong, K. C. Li, \& F. L. Wang (Eds.), Technology in education: Technology-mediated proactive learning (pp. 133-142). Berlin: Springer- Verlag.

Song, L., Singleton, E. S., Hill, J. R., Koh, M. (2004). Improving online learning: Student perceptions of useful and challenging characteristics. The Internet and Higher Education, 7(1), 59-70.

Spahn, K. (1999). Class size and faculty effectiveness and quality. 39th Annual Institutional Research Forum. Seattle, WA.

Stephen, DE, O'Connell, P and Hall, M (2008). Going the extra mile: 'fire fighting', or laissezfaire? Reevaluating personal tutoring relationships within mass higher education. Teaching in Higher Education, 13(4), 449-460.

Stivason T., Saunders G., \& Price J. (2008). A comparison of student performance in an online introductory accounting course with traditional classroom students. College Teaching Methods \& Styles Journal, 4(5), 1-8. 
Sun, P., Tsai, R. J., Finger, G., Chen, Y, and Yeh, D. (2008). What drives a successful e-learning? An empirical Investigation of the critical factors influencing learning satisfaction. Computer \& Education, 50, 1183-1202.

Tello, S. F. (2007). An analysis of student persistence in online education. International Journal of Information and Communication Technology Education, 3(3), 47-62.

Tolu, T. A. (2010). An exploration of synchronous communication in an online preservice ESOL course: Community of inquiry perspective (Unpublished doctoral dissertation). University of South Florida. Retrieved on 5 February 2015 from http://search.proquest. com/docview/822619990? accountid=13654)

Van Der Werf, M. \& Sabatier, G. (2009). The College of 2020: Students. Chronicle Research Services. Retrieved on 5 February 2015 from http://www.warren-wilson.edu/ adcommittee/Tuition_Study/2020Students.pdf.

Vejvodova, J.(2009). The ADDIE model: Dead or alive? Retrieved on 5 February 2015 from http://virtuni.eas.sk/rocnik/2009/pdf/paper_127.pdf)

Vonderwell, S. (2003). An examination of asynchronous communication experiences and perspectives of students in an online course: A case study. Internet and Higher Education, 6, 77-90.

Watters, M. P. \& Robertson, P. (2009). Online delivery of accounting courses: Student perceptions. Academy of Educational Leadership, 13(3), 51-58.

Westerlund, J. (2008). Class size and student evaluations in Sweden. Education Economics, 16(1), 19-28.

White, C. (2003). Independent language learning in distance education: Current issues. Conference on Supporting Independent Language Learning in the 21st Century. Melbourne, Victoria, Australia: University of Melbourne.

Wilson, D. \& Allen, D. (2011). Success rates of online versus traditional college students. Research in Higher Education Journal, 14, 4-12.

Xu, D. \& Jaggars, S. S. (2010). The effectiveness of distance education in Virginia's community colleges: Evidence from introductory college-level math and English courses. Educational Evaluation and Policy Analysis, 33(3), 360-377.

Yildirim, A. \& Simsek, H. (2008). Sosyal bilimlerde nitel arastirma yontemleri ( $6^{\text {th }}$ ed.). Ankara: Seckin.

Zhao, Y., Lei, J., Yan, B., Lai, C., \& Tan, H.S., (2005). What makes the difference? A practical analysis of research on the effectiveness of distance education. Teachers College Record, 107(8), 1836-1884.

Correspondence: Gurhan Durak, Assistant Professor, Department of Computer Education and Instructional Technologies, Necatibey Faculty of Education, Balikesir University, Balikesir, Turkey 